\title{
RISK SHARING AND EFFICIENCY IMPLICATIONS of PROGRESSIVE PENSION ARRANGEMENTS
}

\author{
HANS FEHR \\ CHRISTIAN HABERMANN
}

CESIFO WORKING PAPER NO. 1568

CATEGORY 1: Public FinANCE

OCTOBER 2005

An electronic version of the paper may be downloaded
- from the SSRN website: $\quad$ www.SSRN.com
- from the CESifo website: $\quad$ www.CESifo-group.de 


\title{
RISK SHARING AND EFFICIENCY IMPLICATIONS OF PROGRessive Pension ARRANGEMENTS
}

\begin{abstract}
The present paper aims to quantify the welfare effects of progressive pension arrangements in Germany. Starting from a purely contribution-related benefit system, we introduce basic allowances for contributions and a flat benefit fraction. Since our overlapping-generations model takes into account variable labor supply, borrowing constraints as well as stochastic income risk, we can compare the labor supply, the liquidity, and the insurance effects of the policy reform. Our simulations indicate that for a realistic parameter combination an increase in pension progressivity would yield an aggregate efficiency gain of more than 2 percent of resources. However, such a reform would not be implemented because it would not find political support of the currently living generations.
\end{abstract}

JEL Code: H55, J26.

Keywords: pension reform, idiosyncratic labor income uncertainty.

\author{
Hans Fehr \\ University of Wuerzburg \\ Department of Economics \\ Sanderring 2 \\ 97070 Wuerzburg \\ Germany \\ hans.fehr@mail.uni-wuerzburg.de
}

\author{
Christian Habermann \\ University of Wuerzburg \\ Department of Economics \\ Sanderring 2 \\ 97070 Wuerzburg \\ Germany \\ christian.habermann@mail.uni-wuerzburg.de
}

Previous versions of the paper were presented at the DEMWEL workshop in Paris, the first NETSPAR conference in Tilburg and the RWTH Aachen. We thank Niku Määttänen, Justin van de Ven, Lex Meijdam and other seminar participants for helpful comments and Stefan Zimmermann for excellent research assistance. Financial support from the European Commission's research project "Demographic uncertainty and the sustainability of social welfare systems” (QLK6-CT-2002-02500) is also gratefully acknowledged. 


\section{Introduction}

Since Fenge (1995) it is a standard result in the literature that an intragenerational fair pay-as-you-go pension system is Pareto-efficient. If individual benefits are proportional to former contributions the replacement ratios are constant across income levels and the implicit tax share of the contribution which distorts individual labor supply is minimized, see Sinn (2000). If the link between contributions and benefits is reduced or even destroyed, the implicit tax share of the contribution rises up to 100 percent and, consequently, distortions will increase. For Germany which operates a strictly contribution-related system, some numerical simulations indicate that the efficiency losses from a flat-rate benefit system would be quite substantial, see Fehr (2000). While countries such as Germany, Italy or Spain traditionally operate an intergenerational fair system, other countries such as Japan, US or UK apply a progressive system where the replacement ratios fall with increasing income levels. In order to explain this diversity in the redistributive structure of observed pension systems, Casamatta et al. (2000) as well as Conde-Ruiz and Galasso (2005) apply political-economy models, where the progressivity is determined by the voting outcome. The present paper offers a different explanation. In the following we will argue that a progressive pension system might be optimal if not only the labor market distortions but also the risk-sharing implications are taken into consideration.

The risk-sharing characteristics of alternative tax and social security arrangements have recently gained increasing attention among economists. Krüger and Kubler (2005) show that the introduction of an unfunded social security system can lead to a Paretoimprovement in a model with stochastic production shocks if markets are incomplete and households are fairly risk-avers. Matsen and Thøgersen (2004) derive the optimal mix between funded and unfunded pension saving in a portfolio choice model with wage income, demographic and stock market risk. The adjustment of the pay-go pension budget, on the other hand, determines the intergenerational allocation of such macroeconomic shocks. Thøgersen (1998) as well as Wagener (2003, 2004) demonstrate that a constant contribution rate shifts future economic risks mainly to pensioners while a constant replacement ratio would shift economic risks upon contributors.

Of course, the applied "pension formula" is not only an important intergenerational risksharing device for aggregate shocks, it also might provide an insurance for idiosyncratic shocks. If benefits are strongly linked to former contributions, individual labor income fluctuations are carried to the retirement period. On the contrary, a flat-rate benefit system could be interpreted as an intragenerational risk-sharing device for individual labor income shocks. Since the insurance and the labor supply effect work in opposite direc- 
tions, it is a quantitative question which one dominates the other. Our study aims to quantify the resulting efficiency consequences of a reform to a more progressive pension system in Germany. The numerical analysis is based on an overlapping generations model in the Auerbach-Kotlikoff (1987) tradition. It extends earlier work (Fehr, 2000) by including labor income risk, life-span uncertainty and borrowing constraints. We find that, in contrast to the previous study, a move towards a more progressive pension system yields a potential Pareto-improvement. For our base case parameter choice, the aggregate efficiency gains increase up to 2.13 percent of initial resources.

Since we quantify welfare and efficiency effects of a policy reform, our study can be compared with various other recent numerical papers with idiosyncratic income risk. Huggett and Ventura (1999) quantify the distributional consequences if the current pension system in the US would be substituted by a two-tire system which was proposed by Boskin et al. (1986). Whereas the first tire is strictly connected to former contributions, the tax-financed second tier would guarantee a minimum pension for all households with low income. Their simulations suggest that such a reform would result in welfare losses for the US. However, the analysis is restricted to the steady state, which makes it difficult to interpret their distributional findings. Støresletten et al. (1999) consider the long run effects when the current US pension system is either replaced by a two-tier system of personal saving accounts or completely eliminated. In contrast to Huggett and Ventura (1999), their two-tire system delivers a welfare gain, which is even larger than the gain from privatization. Since their model does not include a labor-leisure choice, the welfare gains are mainly due to general equilibrium effects. The latter are in favor of future generations although the authors try to neutralize the intergenerational income redistribution implied by the reforms.

Huang et al. (1997) were the first who study alternative transition paths of social security privatization in a model with fixed labor supply and idiosyncratic endowment shocks. Whereas in the first experiment social security is terminated immediately and entitled generations are compensated with government bonds, the pension system is phased-out in the second and the government builds up a capital stock to pay for social security retirement benefits in later years. The efficiency gains are larger in the latter experiment which is according to the authors due to the improved public provision of insurance against life span risk and labor income volatility. De Nardi et al. (1999) extend this model by including realistic US demographics and variable labor supply. The latter allows to analyze reforms where the tax-benefit linkage of the pension system is improved, which increases welfare in their framework. Similarly, Conesa and Krueger (1999) extend the Huang et al. (1997) framework by including variable labor supply and idiosyncratic 
efficiency (not endowment) shocks. They simulate an immediate, a gradually and an announced elimination of the pension system and compute the political support for the three proposals. Although for all cases of intra-cohort heterogeneity agents would prefer to be born into the final steady-state, no proposal receives an initial voting majority. Due to the assumed flat pensions in the initial steady-state, the redistribution of the system is abolished if privatization is implemented. Therefore, political support is declining if intra-cohort heterogeneity is increasing.

While Conessa and Krueger (1999) can explain why pension reforms are delayed in democratic systems, their study does not include efficiency calculations. The latter is in the center of our interest. Our approach follows Smetters and Nishiyama (2003) who analyze similar as Conesa and Krueger (2005) a revenue-neutral reform from income to consumption taxation in the US in an OLG model with stochastic labor productivity. The considered reform reduces the labor supply distortions but also the insurance provision of the tax system. Similar as in Auerbach and Kotlikoff (1987) agents are compensated along the transition path and the positive (in the case of overall efficiency gains) or negative (in the case of overall efficiency losses) assets of the Lump-Sum Redistribution Authority are distributed to newborn agents. The present study also follows this approach but in addition also isolates the insurance and labor supply effects numerically.

In the next section, we discuss the general idea of our simulations in a simple framework. Then we describe in brief the German pension system and sketch the structure of the simulation model in section 3. Section 4 explains the calibration and simulation approach. Finally, section 5 presents the simulation results and section 6 offers some concluding remarks.

\section{The optimal progressivity of pension systems}

Table 1 compares the level and the progressivity of different pension systems within the OECD. The progressivity is indicated by the change in the net replacement rates across income levels. Note that in Germany, Italy, Netherlands, Poland and Spain replacement rates are almost constant. All other countries operate a progressive pension system, where a fraction of retirement income consists of flat-rate benefits. Consequently, the net replacement ratios are falling when income levels increase. But replacement rates alone could be misleading as a measure of progressivity. In the UK and Ireland the pension system is progressive on the expenditure and the contribution side. The latter is due to the basic contribution allowance which amounts to 22.8 and 55.4 percent of average income in the UK and Ireland, respectively. In Germany social security contribution rates 
Tabelle 1: Cross country pension levels and progressivity

\begin{tabular}{lcccc}
\hline & \multicolumn{3}{c}{$\begin{array}{c}\text { Net replacement rates by } \\
\text { individual earnings level } \\
\text { Multiple of average }\end{array}$} & $\begin{array}{c}\text { Basic } \\
\text { allowance } \\
\text { in \% of } \\
\text { average wage }\end{array}$ \\
\hline Australia & 0.5 & 1.0 & 2.0 & - \\
France & 97.0 & 52.4 & 36.5 & - \\
Germany & 61.7 & 68.8 & 59.2 & $10.0^{a}$ \\
Ireland & 63.0 & 36.6 & 67.0 & 55.4 \\
Italy & 89.3 & 88.8 & 89.1 & - \\
Japan & 80.1 & 59.1 & 44.3 & - \\
Netherlands & 82.5 & 84.1 & 83.8 & - \\
Poland & 69.6 & 69.7 & 70.5 & - \\
Spain & 88.7 & 88.3 & 83.4 & - \\
UK & 78.4 & 47.6 & 29.8 & 22.8 \\
USA & 61.4 & 51.0 & 39.0 & - \\
OECD average & 84.9 & 69.1 & 61.4 & - \\
\hline
\end{tabular}

Source: OECD (2005), Meister and Ochel (2005).

${ }^{a}$ currently proposed

are reduced if the annual income is below 14.2 percent of average income. However, if the annual income passes this threshold, contribution rates are phased-in again so that finally one has to pay normal contribution rates on the full income. Recently the German trade unions have proposed a reform towards a system of basic allowances which would amount to 10 percent of average income ${ }^{1}$.

In the following we first develop the basic idea of our simulations. In the simplified example, we consider a small open economy where the population growth rate is equal to the world interest rate, i.e. $r=n$. In each period two generations of workers and retirees coexist. Within each working generation, wage earnings $w_{i}$ differ for each individual $i$ from average earnings $\bar{w}$ according to:

$$
w_{i}=\bar{w}+\epsilon_{i} \quad \epsilon_{i} \sim N\left(0 ; \sigma^{2}\right)
$$

Contributions to the pension system depend on the difference between the stochastic gross income $w_{i}$ and the basic allowance $\beta \bar{w}$, where the latter is defined as a fixed fraction $\beta$ of average income. If annual income is below the basic allowance, workers even receive transfers from the pension system. Since we keep the aggregate expenditures constant, the contribution rate $\tau(\beta)$ depends on the level of the basic allowance. In order to define

\footnotetext{
${ }^{1}$ See Meister and Ochel (2005) or Bonin and Schneider (2005).
} 
the contribution function we assume that contributions of the average income households are kept fixed, i.e.

$$
\tau(\beta)(1-\beta) \bar{w}=\tau(0) \bar{w} \quad \Rightarrow \quad \tau(\beta)=\frac{\tau(0)}{1-\beta} \quad \tau^{\prime}(\beta)=\frac{\tau(0)}{(1-\beta)^{2}}>0
$$

When the individual retires, his pension consists of two parts: a (contributory) part which is directly related to his former earnings $w_{i}$ and a (noncontributory) part which is related to average earnings $\bar{w}$, see Casamatta et al. (2000). Since the rate of return of the pay-go scheme is the population growth rate we get

$$
p(\lambda)=(1+n) \tau(0)\left[(1-\kappa \tau(0)) \lambda \bar{w}+(1-\lambda) w_{i}\right]
$$

where $\kappa$ defines the distortion factor and $\lambda$ is the flat benefit fraction of the pension. If $\lambda=0$ pensions are purely contributory, if $\lambda=1$ pension benefits are uniform. Although we do not explicitly model variable labor supply in this simple example, the efficiency consequences of the pension system are indirectly taken into account by $\kappa$. If the basic allowance is zero and pensions are intragenerational fair, the system does not distort labor supply. However, distortions increase if a basic allowance or a flat benefit is introduced. Since we abstract from bequests, individual lifetime income is computed from

$$
y_{i}=w_{i}-(1+\kappa \beta) \tau(\beta)\left[w_{i}-\beta \bar{w}\right]+\tau(0)\left[(1-\kappa \tau(0)) \lambda \bar{w}+(1-\lambda) w_{i}\right]
$$

where we have substituted the assumption $r=n$. Expected lifetime earnings and the respective variance are

$$
\begin{aligned}
E(y) & =\bar{w}\left[1-\kappa \beta \tau(0)-\kappa \lambda \tau(0)^{2}\right] \\
V(y) & =[1-(1+\kappa \beta) \tau(\beta)+(1-\lambda) \tau(0)]^{2} \sigma^{2} .
\end{aligned}
$$

The central trade-off could be already observed in the above formulas: basic allowances and flat benefits induce distortions and reduce the expected lifetime income. However, since both instruments also reduce lifetime income uncertainty they both represent an insurance against income shocks. In order to compute the optimal progressivity of the pension system we apply the simple preference function from Thøgersen (1998)

$$
U(y)=E(y)-\frac{\eta}{2} V(y)
$$

where individual utility increases with expected income and decreases with the uncertainty of income. The parameter $\eta$ defines the individual risk aversion. Substituting (1) and (2) in (3) we get

$$
U(y)=\bar{w}\left[1-\kappa \beta \tau(0)-\kappa \lambda \tau(0)^{2}\right]-\frac{\eta}{2}[1-(1+\kappa \beta) \tau(\beta)+(1-\lambda) \tau(0)]^{2} \sigma^{2} .
$$


From the optimality conditions

$$
\frac{\partial U(y)}{\partial \beta}=0 \quad \text { and } \quad \frac{\partial U(y)}{\partial \lambda}=0
$$

we obtain (after some manipulations) the optimal values

$$
\begin{aligned}
& \beta^{*}=1-\sqrt{(1+\kappa) \tau(0)} \\
& \lambda^{*}=\frac{1-\left(1+\kappa \beta^{*}\right) \tau\left(\beta^{*}\right)+\tau(0)}{\tau(0)}-\frac{\kappa \bar{w}}{\eta \sigma^{2}}
\end{aligned}
$$

Assume for a moment a model with fixed labor supply, i.e. $\kappa=0$. In this case we would get

$$
\beta^{*}=1-\sqrt{\tau(0)}, \quad \tau\left(\beta^{*}\right)=\sqrt{\tau(0)} \quad \text { and } \quad \lambda^{*}=\frac{1-\tau\left(\beta^{*}\right)+\tau(0)}{\tau(0)} .
$$

It is easy to check that for this parameter combination the uncertainty disappears and all households receive a (certain) lifetime income of $\bar{w}^{2}$

With variable labor supply (i.e. $\kappa>0$ ) and a given contribution rate $\tau(0)$, we have

$$
\frac{\partial \beta^{*}}{\partial \kappa}<0, \quad \frac{\partial \lambda^{*}}{\partial \kappa} \gtrless 0, \quad \frac{\partial \lambda^{*}}{\partial \eta}>0, \quad \frac{\partial \lambda^{*}}{\partial \sigma^{2}}>0,
$$

i.e. the optimal basic allowance will be reduced if labor supply $(\kappa)$ is more elastic and the optimal share of flat benefits will increase if households have higher risk aversion $(\eta)$ and are exposed to more income risk $\left(\sigma^{2}\right)$. Labor supply elasticity has an unclear effect on the optimal share of flat benefits. While the direct effect reduces optimal progressivity, the indirect effect (due to $\frac{\partial \beta^{*}}{\partial \kappa}<0$ ) increases it. Finally, there exists a negative relationship between the optimal level of the basic allowance and the optimal flat benefit fraction, i.e. $\frac{\partial \lambda^{*}}{\partial \beta^{*}}<0$.

This basic intuition will not change in a more complex economic environment. The next section presents the simulation model which is applied to quantify the optimal values of $\lambda$ and $\beta$ for the German pension system.

\section{The model economy}

\subsection{Preliminaries}

We consider an economy populated by overlapping generations of individuals which face random survival up to a maximum possible lifespan of $J=16$ periods, i.e. each model

\footnotetext{
${ }^{2}$ The exact value of $\beta^{*}$ is due to technical reasons. It is easy to check that any value of $\beta$ would be feasible since without distortions $\lambda$ could always eliminate the uncertainty.
} 
period covers five years. In addition to lifespan uncertainty, individuals also face productivity shocks during their working time. Labor supply is variable, but consumers are forced to retire at the retirement age $j_{R}=9$ (i.e. real age 60). During retirement, pensioners receive payroll-financed social security benefits and run down their accumulated assets. Apart from the pension system, the government levies a progressive personal tax on income from labor, capital and pensions and proportional taxes on consumption and corporate profits. Tax revenues are used to finance public goods and the interest payments on public debt. The production sector comprises a constant returns to scale Cobb-Douglas production function without technological progress and no aggregate uncertainty.

The initial equilibrium of our model economy is a steady state, then the social security reform is implemented before the individual productivity of the next period is revealed and a new equilibrium path in the assumed closed economy is calculated. We assume zero population growth and keep the survival probabilities constant at initial values. Consequently, all agents face a probability $s_{j}$ of surviving up to age $j$, conditional of surviving up to age $j-1$. Every age $j$ cohort $N_{j}$ is fragmented into subgroups $\xi_{j}(z)$ where $\sum_{z} \xi_{j}(z)=1$ reflecting their state $z$ at a specific age $j$. The state $z=\left(e p_{j}, a_{j}, e_{j}\right)$ of an age $j$ agent describes the agent's earnings points for pension claims $e p_{j}$, asset holdings $\mathrm{a}_{j}$ and efficiency $e_{j}$. In the following, we concentrate on the long run equilibrium and omit the state index $z$ for every variable whenever possible. Agents are then only distinguished according to their age $j$.

\subsection{The individual decision problem}

Our model assumes a preference structure that is represented by a time-separable, nested CES utility function. In order to isolate risk aversion from intertemporal substitution, we follow the approach of Epstein and Zin (1991) and formulate the maximization problem of a representative consumer at age $j$ and state $z$ recursively as

$$
V_{j}(z)=\max _{\ell_{j}, c_{j}}\left\{u\left(c_{j}, \ell_{j}\right)^{1-\frac{1}{\gamma}}+\frac{s_{j+1}}{1+\theta}\left[\sum_{e_{j+1}} \pi\left(e_{j+1} \mid e_{j}\right) V_{j+1}\left(z^{\prime}\right)^{1-\eta}\right]^{\frac{1-\frac{1}{\gamma}}{1-\eta}}\right\}^{\frac{1}{1-\frac{1}{\gamma}}}
$$

where $\ell_{j}$ and $c_{j}$ denote leisure and consumption at age $j$ respectively and the parameter $\theta$ represents the "pure" rate of time preference. Since lifespan is uncertain, the expected utility in future periods is weighted with the survival probability $s_{j+1}$. Productivity $e_{j}$ at each age $j$ is uncertain and depends on the productivity in the previous period. Consequently, $\pi\left(e_{j+1} \mid e_{j}\right)$ denotes the probability to experience productivity $e_{j+1}$ in the next 
period if the current productivity is $e_{j}$. The parameters $\gamma$ and $\eta$ define the intertemporal elasticity of substitution between consumption and leisure in different years and the degree of (relative) risk aversion, respectively. Note that for the special case $\eta=\frac{1}{\gamma}$ we are back at the traditional expected utility specification, see Epstein and Zin $(1991,266)$. The period utility function is defined by

$$
u\left(c_{j}, \ell_{j}\right)=\left[\left(c_{j}\right)^{1-\frac{1}{\rho}}+\alpha\left(\ell_{j}\right)^{1-\frac{1}{\rho}}\right]^{\frac{1}{1-\frac{1}{\rho}}}
$$

where $\rho$ denotes the intratemporal elasticity of substitution between consumption and leisure at each age $j$. Finally, the leisure preference parameter $\alpha$ is assumed to be age independent. The budget constraint is defined as follows:

$$
\mathrm{a}_{j+1}=\mathrm{a}_{j}(1+r)+w_{j}\left(1-\tau_{j}\right)+p_{j}-T\left(y_{j}\right)-\left(1+\tau^{c}\right) c_{j}+b_{j}
$$

with $a_{1}=a_{J+1}=0$ and $a_{j} \geq 0 \forall j$. In addition to income from savings, households receive gross labor income $w_{j}=\left(1-\ell_{j}\right) w e_{j}$ but have to pay progressive income taxes $T\left(y_{j}\right)$ and pension contributions $\tau_{j}$. Due to the basic allowance and a contribution ceiling the average contribution rate depends on income. We define the progressive tax function $T(\cdot)$ which computes the income tax burden from taxable income $y_{j}$. The price of consumption goods $\left(1+\tau^{c}\right)$ includes consumption taxes, $p_{j}$ is the pension payment after retirement and $r$ defines the gross interest rate. Since we abstract from annuity markets, agents who die might leave positive assets. Those assets are aggregated and distributed among all cohorts following an exogenous age-dependent distribution scheme ${ }^{3}$, where an age $j$ agent receives the accidental bequests $b_{j}$.

The taxable income $y_{j}$ in (6) is derived from gross labor and capital income and (after retirement) a fraction $\psi$ of pension payments:

$$
y_{j}=w_{j}+\psi p_{j}+\max \left[\mathrm{a}_{j} r-d^{s} ; 0\right]-d_{j} .
$$

Households only have to tax capital income if it exceeds a certain limit $d^{s}$ (Sparerfreibetrag). In addition, they can deduct a fixed work related allowance and parts of their contributions to the pension system. The sum of individual allowances is computed in the deduction amount $d_{j}$.

\subsection{The production side}

The economy is populated by a large number of competitive firms, the sum of which we normalize to unity. Aggregate output $Y$ is produced using a Cobb-Douglas production

\footnotetext{
${ }^{3}$ The latter is computed from socio-economic panel (SOEP) data of 2001.
} 
technology, i.e.

$$
Y=\varrho K^{\varepsilon} L^{1-\varepsilon}
$$

where $K$ and $L$ are aggregate capital and labor, $\varepsilon$ is capital's share in production, and $\varrho$ is a technology parameter. Firms have to pay corporate taxes $T^{k}=\tau^{k}[Y-w L-\delta K]$ where the corporate tax rate $\tau^{k}$ of 15 percent is applied to the output net of labor costs $w L$ and depreciation $\delta K$.

Firms will employ labor up to the point where the marginal product of labor equals labor costs. Similarly they will employ capital up to the point where the net marginal product of capital is equal to the interest rate:

$$
\begin{aligned}
w & =(1-\varepsilon) \varrho\left(\frac{K}{L}\right)^{\varepsilon} \\
r & =\left(1-\tau^{k}\right)\left[\varepsilon \varrho\left(\frac{L}{K}\right)^{1-\varepsilon}-\delta\right]
\end{aligned}
$$

\subsection{The government}

In each period the government issues new debt $\Delta B$ and collects taxes and social security contributions from households and firms in order to finance general government expenditures $G$ as well as interest payments on its debt:

$$
\Delta B+\sum_{j} \sum_{z}\left[T\left(y_{j}(z)\right)+\tau^{c} c_{j}(z)\right] \xi_{j}(z) N_{j}+T^{k}=G+r B .
$$

With respect to public debt, we assume that the government maintains an exogenously fixed debt to capital ratio. General government expenditures $G$ consist of government purchases of goods and services which are fixed per capita. In order to balance the budget each period, the consumption tax rate $\tau^{c}$ is adjusted.

In each year, the pension system pays old-age benefits and collects payroll contributions from wage income above the basic allowance and below the contribution ceiling. In the initial equilibrium the basic allowance is zero while the contribution ceiling is fixed at two times the average income. Individual pension benefits $p_{j}$ of a retiree of age $j \geq j_{R}$ in a specific year are computed from the product of his earning points $e p_{j_{R}}$ the retiree has accumulated at retirement and the actual pension amount $(A P A)$ of the respective year:

$$
p_{j}=e p_{j_{R}} \times A P A .
$$

The accumulated earning points consist of two parts: The first part depends on the relative income position $\min \left[w_{j} / \bar{w} ; 2.0\right]$ of the worker at working age $j<j_{R}$. Since the 
contribution ceiling is fixed at the double of average income, the maximum earning points that could be collected are 2. The earning point of the second part is normalized to one and therefore independent of individual income. The weights are $(1-\lambda)$ and $\lambda$, respectively. Accumulated earning points at age $j$ are therefore

$$
e p_{j}=e p_{j-1}+\min \left[w_{j} / \bar{w} ; 2.0\right](1-\lambda)+\lambda .
$$

The actual pension amount $(A P A)$ in equation (12) is adjusted in each period in order to yield a standard pension (i.e. where $e p_{j_{R}}=j_{R}-1$ ) which amounts to sixty percent of net average earnings.

The budget of the pension system must be balanced in each period. Therefore, the general contribution rate $\tau$ has to be adjusted to fulfill the period budget constraint

$$
\sum_{j=j_{R}}^{J} \sum_{z} p_{j}(z) \xi_{j}(z) N_{j}=\tau \sum_{j=1}^{j_{R}-1} \sum_{z} \max \left[\min \left[w_{j}(z) ; 2.0 \bar{w}\right]-\beta \bar{w} ; 0\right] \xi_{j}(z) N_{j} .
$$

The right hand side of equation (14) shows the individual contribution base. Households don't pay contribution on income below the basic allowance and above the contribution ceiling. Note that the general social security contribution rate $\tau$ which is calculated from (14) is not necessarily identical with the individual contribution rates in the budget constraint (6). The latter is given by

$$
\tau_{j}=\left\{\begin{array}{lrr}
0 & \text { if } & w_{j}<\beta \bar{w} \\
\tau\left[w_{j}-\beta \bar{w}\right] / w_{j} & \text { if } & \beta \bar{w} \leq w_{j} \leq 2.0 \bar{w} \\
\tau[2.0-\beta] \bar{w} / w_{j} & \text { if } & w_{j}>2.0 \bar{w}
\end{array}\right.
$$

Of course, the basic allowance and the contribution ceiling create a non convexity in the budget constraint similar as the progressive income tax schedule. However since we model individual pension claims as a state variable and optimize labor supply over discrete grid points, we do not need the first-order conditions (and the included marginal tax and contribution rates) from the optimization problem.

\section{Calibration}

In order to solve the model we have to specify the income process, preference and technology parameters and tax rates. This section presents our parameter choices and describes the initial equilibrium. 


\subsection{The income process}

We consider six productivity profiles across the life cycle. The four top profiles are directly taken from Fehr (1999) while the lowest profile from the previous study has been split up in order to improve the income distribution. When an agent enters the labor market (at age 20-24) he belongs to the lowest productivity level with a probability of 10 percent, to the second lowest again with 10 percent and to higher levels with 20 percent, respectively. After the initial period, agents change their productivity levels according to the following Markov transition matrix.

Tabelle 2: Markov transition matrix

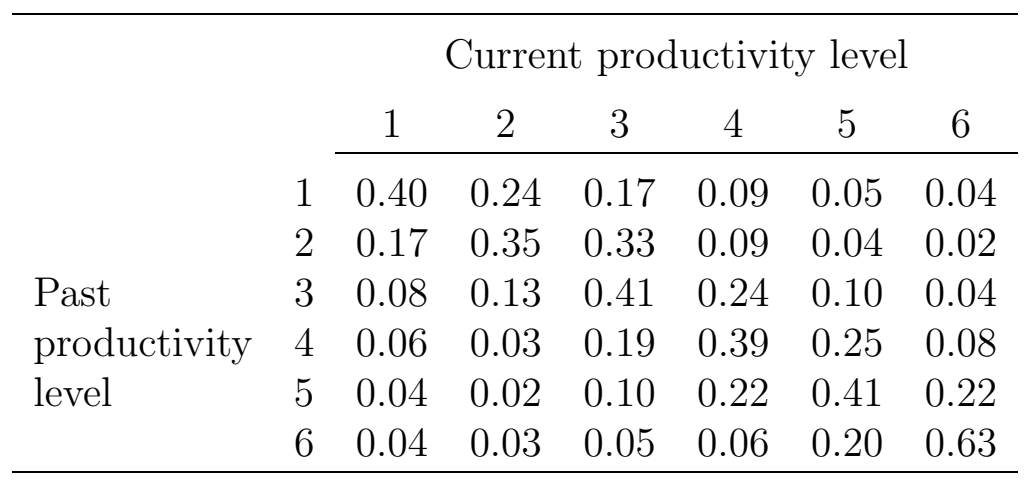

Source: Authors' own calculations from 1998/2003

SOEP data

The Markov transition matrix is calculated as follows: First the primary earners in each household of the 1998 survey are ranked according to their gross income and then divided into six income classes. Then we rank and compute the respective income class of those persons who are still in the survey in 2003. Finally we calculate the above reported transition probabilities for each income class.

\subsection{Preferences, technology and demographics}

Table 3 reports the other important parameter values. A discussion of preference and technology parameters can be found in Auerbach and Kotlikoff (1987, 52f.) or Fehr $(1999,57)$. The literature typically perceives values for the coefficient of relative risk aversion between 1 and 5 as reasonable, values above 10 are considered unrealistic, see Cecchetti et al. (2000, 792). This perception is consistent with the evidence from survey questions, see Barski et al. (1997) for the US or Dohmen et al. (2005) for Germany.

The taxation of income (labor and capital income and pensions) is very close to the German income tax code after the reforms in 2004. The taxable share of pensions $\psi$ is 0.32 . 
Tabelle 3: Parameter values of the model

\begin{tabular}{lll}
\hline & Symbol & Value \\
\hline Utility function & & \\
time preference rate (p.a.) & $\theta$ & 0.01 \\
intertemporal elasticity of substitution & $\gamma$ & 0.5 \\
intratemporal elasticity of substitution & $\rho$ & 0.6 \\
coefficient of relative risk aversion & $\eta$ & 4.0 \\
leisure preference parameter & $\alpha$ & 1.5 \\
Production function & & \\
technology level & $\varrho$ & 1.48 \\
capital share in production & $\varepsilon$ & 0.30 \\
economic depreciation (p.a.) & $\delta$ & 0.05 \\
\hline
\end{tabular}

Employees are allowed to deduct 50 percent of their pension contributions (the employers share) and the remaining 50 percent (i.e. the employees' share) up to a maximum of 2000 $€$. We assume that our individuals are married couples with a sole wage earner and apply the German income splitting method. For capital income there is a special allowance of $d^{s}=1800 €$ (per couple) ${ }^{4}$. Figure 1 shows the marginal tax rate schedule introduced in Germany in 2005.

Abbildung 1: Marginal tax rate schedule T05

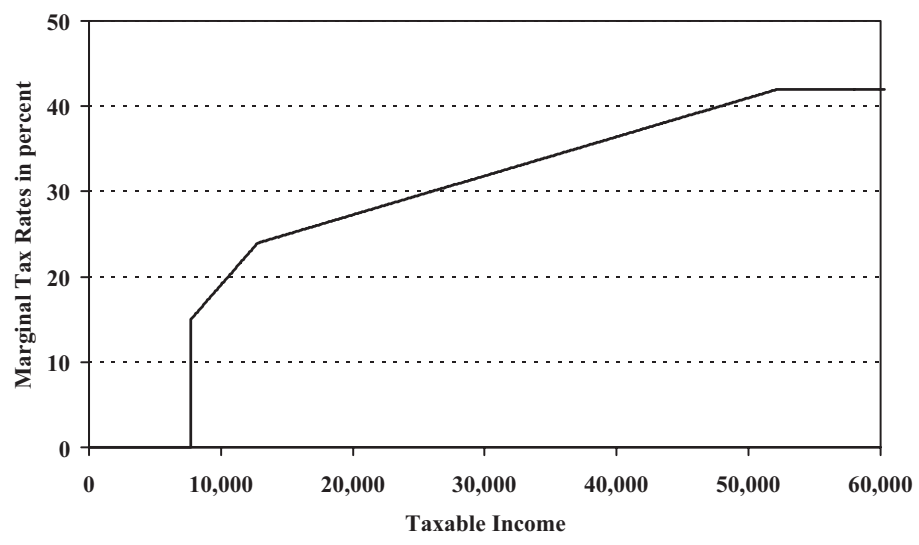

Finally, with respect to the demographic parameters we compute average survival probabilities from Bomsdorf (2003) for the ages 20 to 99.

\footnotetext{
${ }^{4}$ In Germany this allowance is $3000 €$ for nominal interest income, but in our model we have no inflation and therefore we reduce this amount by about 40 percent.
} 


\subsection{Initial equilibrium}

Table 4 reports the structure of the models initial equilibrium (where $\lambda=\beta=0$ ) and compares it with the respective actual figures for 2003. All in all, the model represents the basic economic and fiscal structure of Germany quite well. Since the model is simulated as a closed economy, the interest rate is endogenous and the trade balance is zero. The key characteristics of the tax and pension system match the current German situation.

Tabelle 4: The initial equilibrium

\begin{tabular}{lrr}
\hline & Model & $\begin{array}{r}\text { Germany } \\
2003^{*}\end{array}$ \\
\hline Expenditures on GDP (\% of GDP) & & \\
private consumption & 63.3 & 58.6 \\
government purchases & 18.9 & 19.3 \\
gross investment & 17.9 & 17.8 \\
exports-imports & - & 4.3 \\
Government indicators & & \\
aggregate pension benefits (\% of GDP) & 13.0 & 12.7 \\
pension contribution rate (in \%) & 19.3 & 19.5 \\
Tax revenues (in \% of GDP) & 20.9 & 20.7 \\
$\quad$ income tax & 7.7 & 7.4 \\
$\quad$ consumption tax & 11.4 & 10.7 \\
$\quad$ corporation tax & 1.8 & 1.7 \\
consumption tax rate (in \%) & 18.0 & - \\
& & \\
interest rate p.a. (in \%) & 3.1 & - \\
capital-output ratio & 3.1 & 3.5 \\
\hline
\end{tabular}

*Source: Institut der deutschen Wirtschaft (2004).

Table 5 shows the distribution for net income and assets respectively. The percentage share of income (assets) is the share that accrues to subgroups of the population ranked by net income (assets). Our initial equilibrium replicates the German income distribution quite well, however, it underestimates the wealth inequality ${ }^{5}$. Finally, 40 percent of labor market entrants (i.e. the three lowest income classes) would like to borrow on the capital market in the initial equilibrium. For the following generations this fraction falls to 9,6 , and 1.5 percent, respectively.

\footnotetext{
${ }^{5}$ The latter is quite common in numerical models. Heer and Trede $(2003,96)$ point out that it might
} 
Tabelle 5: Income and Wealth Distribution

\begin{tabular}{|c|c|c|c|c|}
\hline & & Percentage & of income/assets & Gini \\
\hline & & Lowest $10 \%$ & Highest $10 \%$ & index \\
\hline Model & Net income & 3.4 & 22.2 & 0.287 \\
\hline & Assets & 0.0 & 30.4 & 0.518 \\
\hline Germanv* & Net income & 3.1 & 23.9 & 0.299 \\
\hline & Assets & 0.2 & 44.2 & 0.613 \\
\hline
\end{tabular}

* Source: DIW $(2005,202)$

This should suffice to explain our calibration and initial equilibrium. Next we turn to the policy reforms and their risk and efficiency implications.

\section{$5 \quad$ Simulation Findings}

This section compares the macroeconomic and welfare consequences of a switch from the current contribution-related to a more progressive pension system in Germany. Before the numerical results of the simulations are presented, we first explain the computation of the welfare changes.

\subsection{Experimental Design and Social Welfare}

In order to find the optimal values for $\beta$ and $\lambda$, we increase both parameters from their benchmark value of zero. As a consequence, the tax-benefit linkage will be reduced, the marginal contribution rate will increase, and labor market distortions will rise. But the higher progressivity also improves the risk-sharing characteristics of the pension system. The welfare criterion we use to assess this reform is ex-ante expected utility of an agent, before the productivity level is revealed (i.e. looking upon her life behind the Rawlsian veil of ignorance). For an agent who enters the labor market the expected utility is computed from

$$
V=\left[\sum_{i=1}^{6} \pi_{i} V_{i}^{1-\eta}\right]^{\frac{1}{1-\eta}}
$$

where $\pi_{1}=\pi_{2}=0.1$ and $\pi_{3}=\cdots=\pi_{6}=0.2$. From that point of view one has some desire for redistribution, which provides insurance for being born as a low-productivity type. Following Auerbach and Kotlikoff $(1987,87)$ we compute the proportional increase be due to the neglected business ownership. 
in consumption and leisure $(W)$ which would make an agent in the baseline scenario as well off as in the reform scenario. If the expected utility level after the reform is $\hat{V}$ and the expected utility level on the baseline path is $\bar{V}$, the necessary increase (decrease) in percent of initial resources is computed from

$$
W=\left[\left(\frac{\hat{V}}{\bar{V}}\right)-1\right] \times 100 .
$$

Consequently, a value of $W=1.0$ indicates that this agent would need one percent more resources in the baseline scenario to attain expected utility $\hat{V}$.

In order to asses the aggregate efficiency consequences, we introduce a Lump-Sum Redistribution Authority (LSRA) in the spirit of Auerbach and Kotlikoff (1987, 65f.) as well as Nishiyama and Smetters (2003, 29f.). The LSRA pays a lump-sum transfer (or levies a lump-sum tax) to each living household in the first period of the transition to bring their expected utility level back to the level of the initial equilibrium. Since utility depends on age and state, these transfers (or taxes) have to be computed for every agent in period one. Note that transfers differ only between the states of the earning points $e p_{j}$ and asset holdings $a_{j}$ but not between efficiencies for agents with the same $e p_{j}$ and $a_{j}$. That is because the reform is announced before the productivity shock in period 1 is revealed. Consequently, age- $j$ agents who already worked before the reform are compensated by the transfers $v_{j 1}(\bar{V}(z))$, which guaranties for each individual at state $z$ the initial expected utility level $\bar{V}(z)$. On the other hand, those who enter the labor market in period $t$ of the transition receive a transfer $v_{1 t}\left(V^{*}\right)$ which guaranties them an expected utility level $V^{*}$. Note that the transfers $v_{1 t}$ may differ among future cohorts but the expected utility level $V^{*}$ is identical for all. The value of the latter is chosen by requiring that the present value of all LSRA transfers is zero:

$$
\sum_{j=2}^{J} \sum_{z} v_{j 1}(z, \bar{V}) \xi_{j}(z) N_{j}+\sum_{t=1}^{\infty}\left[\Pi_{k=0}^{t}\left(1+r_{k}\right)^{-1}\right] v_{1 t}\left(V^{*}\right) N_{1}=0
$$

With $V^{*}>\bar{V}$ (i.e. $W>0$ ), all households in period one who have lived in the previous period would be as well off as before the reform and all current and future newborn households would be strictly better off. Hence, the new policy is Pareto improving after lump-sum redistributions. With $V^{*}<\bar{V}$ (i.e. $W<0$ ), the policy reform is Pareto inferior after lump-sum redistributions. In order to asses the overall efficiency of the reform we will report the value of $W$ after compensation in the following tables. 


\subsection{Numerical Results for the Benchmark Calibration}

In order to discuss the macroeconomic and long run welfare consequences, we consider in Table 6 a scenario where half of the pension consists of flat benefits and the basic allowance amounts to 30 percent of average income (i.e. $\lambda=0.5$ and $\beta=0.3$ ). Since this reform reduces the tax-benefit linkage and increases contributions, labor supply, employment, consumption and GDP fall which in turn reduce aggregate savings and (one period later) the capital stock. Initially wages increase, but due to the crowding out of capital they fall back even below the initial level during the transition. Due to the basic allowance contribution rates have to increase by almost 10 percent. However, since the reform only changes the progressivity of the system, aggregate pension outlays remain almost constant during the transition. Finally, since income tax revenues are reduced and the consumption tax base is smaller, consumption tax rates have to increase in order to balance the budget.

Tabelle 6: Macroeconomic effects of progressive pensions

\begin{tabular}{lrrrrrrr}
\hline Period & $2005-09$ & $2015-19$ & $2025-29$ & $2035-39$ & $2045-49$ & $2055-59$ & $\infty$ \\
\hline Employment $^{a}$ & -5.2 & -4.5 & -4.1 & -4.1 & -4.1 & -4.2 & -4.1 \\
Consumption $^{a}$ & -3.5 & -4.7 & -5.2 & -5.5 & -5.7 & -5.8 & -6.0 \\
GDP $^{a}$ & -3.7 & -4.3 & -4.5 & -4.7 & -4.9 & -5.0 & -5.1 \\
Capital stock $^{a}$ & 0.0 & -3.8 & -5.5 & -6.2 & -6.6 & -6.9 & -7.4 \\
Wage $^{a}$ & 1.6 & 0.2 & -0.4 & -0.7 & -0.8 & -0.9 & -1.1 \\
Interest rate p.a. $^{b}$ & -0.3 & 0.0 & 0.1 & 0.1 & 0.1 & 0.1 & 0.2 \\
Contribution rate $^{b}$ & 9.6 & 9.5 & 9.3 & 9.1 & 9.3 & 9.6 & 9.8 \\
Pension outlays $^{c}$ & 13.0 & 13.0 & 12.9 & 12.8 & 12.9 & 13.0 & 13.1 \\
Consumption tax $^{b}$ & 2.0 & 2.0 & 2.0 & 2.1 & 2.2 & 2.2 & 2.3 \\
\hline
\end{tabular}

${ }^{a}$ Changes are reported in percentage over baseline simulation

${ }^{b}$ Changes in percentage points. ${ }^{c}$ in $\%$ of GDP

Figure 2 reports the average ex-ante expected welfare changes for current and future agents computed from (16). ${ }^{6}$ Given the negative long-run macroeconomic consequences from Table 6, one would expect that at least all future agents are worse of with a progressive pension system. However, this basic intuition is misleading, since it neglects the insurance effects of the reform. As Figure 2 shows, the reform clearly reduces the welfare of most elderly households while younger and future living households gain. Due to the increase in

\footnotetext{
${ }^{6}$ Since we have to distinguish agents living in the reform year according to their current state, we report in Figure 2 the average welfare change for each cohort.
} 
Abbildung 2: Welfare effects of progressive pensions

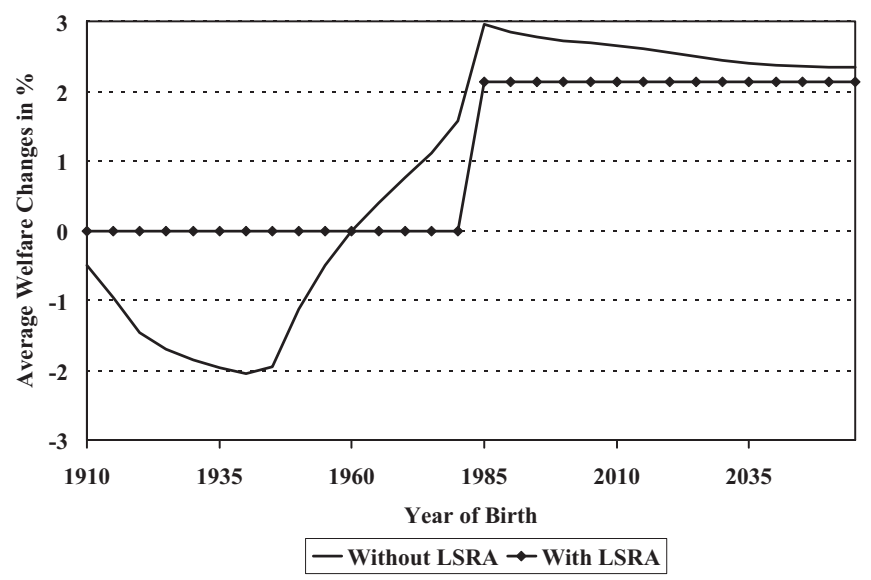

consumption taxes, elderly who are already retired (i.e. are born before 1940) lose up to 2 percent of remaining lifetime income. Since workers benefit from the improved insurance effects, households who are born after 1960 realize increasing welfare gains which reach a maximum for those who enter the labor market in the reform year 2005. For future workers, welfare effects are still positive but decrease again due to the long-run fall in wages. Figure 2 also shows that the considered progressive pension reform would yield a Pareto-improvement! If all current households are compensated with LSRA transfers, young and future households could still experience a welfare increase which amounts to 2.13 percent of initial resources.

The upper part of Table 7 reports the compensated welfare gains for alternative levels of the basic allowance and flat-benefit shares. Without a basic allowance the insurance effect always dominates the labor supply effect. Consequently, the first line shows an efficiency gain which rises with the flat-benefit level. The introduction of basic allowances increases the efficiency gains initially, since the latter not only provides an insurance, but also reduces the liquidity constraints of some households. As already indicated in the basic model of section 2, the basic allowance reduces the optimal share of flat benefits. Since labor supply distortions are also rising with the allowance level, the highest efficiency gain is computed with the combination $\beta=0.3$ and $\lambda=0.5$ from Table 6 above.

In order to isolate the insurance effect of a specific reform, the middle part of Table 7 reports the efficiency consequences for risk neutral preferences (i.e. $\eta=0$ ), which of course are due to labor supply and liquidity effects. In most cases the losses due to higher labor supply distortions dominate the potential gains from improved liquidity and overall efficiency declines. It should not be surprising that the efficiency losses are increasing with the progressivity of the system. Finally, the insurance effect of a specific reform can 
be roughly recovered from the difference between the respective figures in top and middle part of Table 7.7

Tabelle 7: Compensated welfare changes: Benchmark*

\begin{tabular}{|c|c|c|c|c|c|}
\hline$\beta$ & & & $\lambda$ & & \\
\hline \multicolumn{6}{|c|}{ insurance, liquidity and labor supply effect } \\
\hline & 0.00 & 0.25 & 0.50 & 0.75 & 1.00 \\
\hline 0.0 & 0.00 & 0.55 & 0.97 & 1.14 & 1.32 \\
\hline 0.1 & 0.69 & 1.12 & 1.43 & 1.64 & 1.61 \\
\hline 0.2 & 1.37 & 1.76 & 2.04 & 2.05 & 2.06 \\
\hline 0.3 & 1.73 & 2.00 & 2.13 & 2.04 & 1.73 \\
\hline 0.4 & 1.75 & 1.84 & 1.77 & 1.46 & 1.05 \\
\hline \multicolumn{6}{|c|}{ liquidity and labor supply effect } \\
\hline & 0.00 & 0.25 & 0.50 & 0.75 & 1.00 \\
\hline 0.0 & 0.00 & -0.23 & -0.47 & -0.78 & -1.19 \\
\hline 0.1 & -0.02 & -0.22 & -0.51 & -0.90 & -1.32 \\
\hline 0.2 & 0.05 & -0.25 & -0.58 & -1.01 & -1.53 \\
\hline 0.3 & -0.22 & -0.57 & -1.00 & -1.53 & -2.17 \\
\hline 0.4 & -0.84 & -1.29 & -1.84 & -2.50 & -3.29 \\
\hline \multicolumn{6}{|c|}{ labor supply effect } \\
\hline & 0.00 & 0.25 & 0.50 & 0.75 & 1.00 \\
\hline 0.0 & 0.00 & -0.18 & -0.49 & -0.82 & -1.24 \\
\hline 0.1 & -0.14 & -0.38 & -0.66 & -1.06 & -1.54 \\
\hline 0.2 & -0.32 & -0.60 & -0.96 & -2.15 & -1.95 \\
\hline 0.3 & -0.67 & -1.04 & -1.49 & -2.04 & -2.67 \\
\hline 0.4 & -1.38 & -1.87 & -2.42 & -3.05 & -3.82 \\
\hline
\end{tabular}

${ }^{*}$ In percentage of remaining resources.

Finally, we separate the labor supply and the liquidity effect by removing the borrowing constraints in the last part of Table 7 . We run these simulations with risk neutral preferences. Consequently, the reported figures show the pure labor supply effect, while the difference between the respective numbers in the middle and last part of Table 7 isolate (roughly) the liquidity effect of each reform. Note first that for $\beta=0$ the efficiency gains in the middle and last part of Table 7 are almost identical. Since with risk neutral preferences a more progressive pension system will not alter savings behavior dramatically, the liquidity effect is close to zero. On the other hand, the efficiency losses of the first column are now higher than before, since the basic allowance does not relax the borrowing

\footnotetext{
${ }^{7}$ However, one has to keep in mind that also the initial equilibria in the top and middle part slightly differ. Consequently, the percentage figures refer to different bases.
} 
constraints any more (as in the upper part). Finally, note that the liquidity effect rises with $\beta$.

Given the welfare consequences of the reform for the different households, we follow Conessa and Krueger $(1999,2005)$ and check whether the the optimal progressivity level $\lambda=0.5$ and $\beta=0.3$ is politically feasible. Consequently, we compute the fraction of each cohort living in the initial equilibrium which would benefit from the reform and match these figures with the population structure in Germany in 2001. Figure 3 shows on the left axis the fraction of the respective cohort which benefits and, consequently, is in favor of the reform. Of course, all elderly will lose and all entrants in the labor market will gain. In the middle-age-cohort the productivity realization and the remaining time horizon until retirement determines the judgement of the reform. In general high productivity types are against the reform, whereas a long time horizon works in favor of the reform. Consequently, at younger ages only high productivity types are against the reform while with rising age more and more lower productivity agents join the group of opponents.

Abbildung 3: Political feasibility of the reform: Benchmark

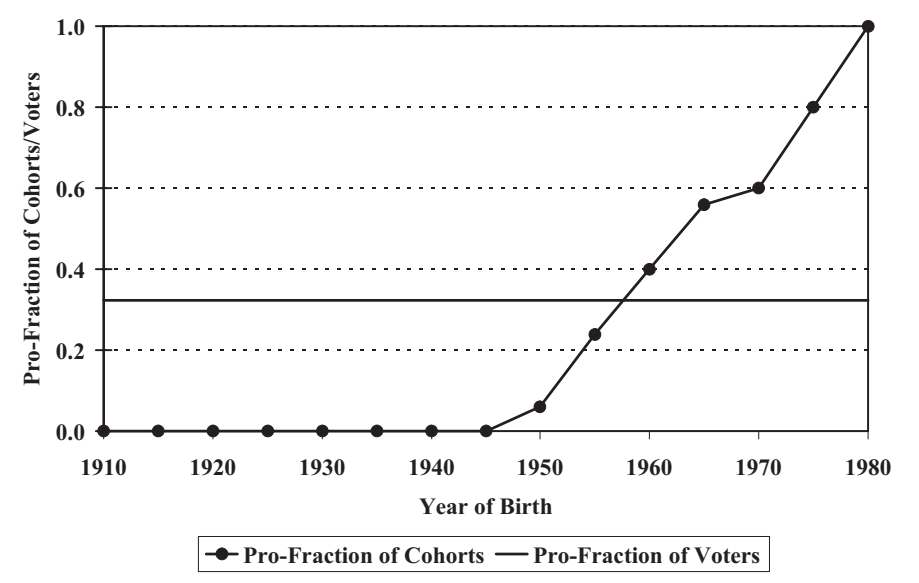

If we combine the pro-shares of the various cohorts from Figure 3 with the German population data, we arrive at a fraction of only 34.9 percent of total voters who will be in favor of the reform. Consequently, we conclude for our benchmark calibration, that a more progressive pension system would be rejected by a majority of voters, although it yields a potential Pareto-improvement.

\subsection{Sensitivity Analysis}

In our benchmark calibration of Table 3, the intertemporal substitution elasticity $(\gamma)$ is fairly high, compared to the standard calibration in Auerbach and Kotlikoff (1987). 
Consequently, in the upper part of Table 8 we reduce this parameter to 0.25 . As a consequence, the optimal consumption profile of households becomes flatter. The impact on aggregate efficiency is quite different for flat benefits and basic allowances. If flat benefits are introduced, young and poor households would like to increase their current consumption more than in the benchmark. Consequently, the borrowing constraint bites more than before which dampens the efficiency gains of flat benefits in the first line of Table 8 compared to the respective figures in Table 7. On the other hand, the flatter optimal consumption profile also implies that the borrowing constraints now bite stronger for young and poor households in the initial equilibrium. Consequently, the liquidity effects of the basic allowance are stronger which increases the efficiency gains in the first column of Table 8 compared to the respective figures in Table 7 .

Next we change the labor supply elasticity. The assumed intratemporal substitution elasticity $(\rho)$ of 0.6 from Table 3 implies in the initial equilibrium an uncompensated wage elasticity of labor supply of -0.03 and a compensated elasticity of 0.24 . The figure for the uncompensated elasticity is in line with the empirical literature. A recent study by Flood et al. (2003) reports estimates for uncompensated wage elasticities which range from -0.04 to 0.15 , the reported figure for Germany was 0.0. Of course, the compensated elasticity is responsible for the computed labor supply distortions. In the middle part of Table 8 we increase the intratemporal substitution elasticity to 0.7 which yields an uncompensated labor supply elasticity of 0.0 and a compensated elasticity of 0.29 . As one would expect, the efficiency gains from pension progressivity are sharply reduced compared to the benchmark case of Table 7 . The most extreme combination in Table 8 now even yields aggregate efficiency losses. The optimal combination is now $\beta=0.2$ and $\lambda=0.5$, which is clearly in line with the predictions from section 2 .

Finally, we alter the relative risk aversion $(\eta)$ from Table 3. Although the benchmark value of $\eta=4$ is fairly $l_{0}{ }^{8}$, we reduce the coefficient of relative risk aversion further from 4 to 2 in the lower part of Table 8 . Not surprisingly, the aggregate efficiency gains fall sharply compared to Table 7 . Without basic allowances the optimal share of flat pensions is now only 50 percent. If basic allowances are introduced, the optimal level is now 20 percent of average income and the respective flat benefit share is 25 percent. Note that the efficiency gain of the optimal combination is reduced sharply from 2.13 percent (in Table 7) to 0.70 percent of remaining resources.

Of course, if we combine low risk aversion and high labor supply elasticities, the efficiency

\footnotetext{
${ }^{8}$ In an attempt to extract the degree of relative risk aversion from hypothetical questions administered to a sample of respondents in the Health and Retirement Survey, Barsky et al. (1997) find evidence that a substantial proportion of people is much more risk averse.
} 
Tabelle 8: Compensated welfare changes: Sensitivity analysis*

\begin{tabular}{ccccccccc}
\hline$\gamma$ & $\rho$ & $\eta$ & $\beta$ & & \multicolumn{5}{c}{$\lambda$} \\
0.25 & 0.6 & 4.0 & 0.0 & 0.00 & 0.30 & 0.55 & 0.63 & 0.64 \\
& & & 0.1 & 1.15 & 1.37 & 1.55 & 1.55 & 1.52 \\
& & & 0.2 & 2.21 & 2.42 & 2.59 & 2.52 & 2.39 \\
& & & 0.3 & 2.69 & 2.84 & $\mathbf{2 . 8 7}$ & 2.59 & 2.37 \\
& & & 0.4 & 2.55 & 2.47 & 2.29 & 1.99 & 1.67 \\
0.5 & 0.7 & 4.0 & 0.0 & 0.00 & 0.43 & 0.60 & 0.72 & 0.83 \\
& & & 0.1 & 0.54 & 0.87 & 1.05 & 1.09 & 0.95 \\
& & & 0.2 & 1.09 & 1.32 & $\mathbf{1 . 4 1}$ & 1.28 & 0.88 \\
& & & 0.3 & 1.26 & 1.22 & 1.22 & 1.03 & 0.73 \\
& & & 0.4 & 1.09 & 0.94 & 0.77 & 0.08 & -0.55 \\
0.5 & 0.6 & 2.0 & 0.0 & 0.00 & 0.10 & 0.17 & 0.07 & -0.16 \\
& & & 0.1 & 0.32 & 0.42 & 0.42 & 0.20 & -0.04 \\
& & & 0.2 & 0.66 & $\mathbf{0 . 7 0}$ & 0.51 & 0.22 & -0.01 \\
& & & 0.3 & 0.68 & 0.59 & 0.39 & 0.12 & -0.37 \\
& & & 0.4 & 0.47 & 0.21 & -0.12 & -0.70 & -1.35 \\
\hline
\end{tabular}

*In percentage of remaining resources.

gains will fall further. For the combination $\eta=2.0$ and $\rho=0.7$ the optimal progressivity parameters would be $\beta=0.2, \lambda=0.0$ and the aggregate efficiency gain would fall to 0.42 percent of resources. We also simulated the optimal benchmark reform of Table 7 in a small open economy. Without factor price repercussions the aggregate efficiency gains slightly increase from 2.13 to 2.32 percent, but the basic intuition does not change. Finally, we have fixed the consumption tax rate and introduced a payroll tax in order to balance the budget. Due to the annual net-income adjustment of the actual pension amount the pension level falls now compared to the benchmark reforms. The compensated and uncompensated welfare changes, however, are hardly affected.

\section{Conclusion}

The present paper develops a pure welfare theoretic argument in favor of widely used progressive pension arrangements. Simulating the switch from the current purely contributionrelated system towards a more progressive pension system in Germany, we find significant efficiency gains. For our benchmark calibration the latter amount to more than 2 percent of aggregate resources. The efficiency gains are due to a (positive) insurance effect, a (positive) liquidity effect and a (negative) labor supply effect which are isolated in the 
numerical simulations. For our benchmark calibration we find an optimal flat benefit share in overall pension benefits of 50 percent and an optimal basic allowance of 30 percent of average income. Of course, the optimal progressivity is sensitive to the assumed parameter specification but as long as households are reasonable risk averse we always find a significant aggregate efficiency gain when moving to a more progressive system.

Our distributional analysis also yields some evidence why the proposed reform has not been implemented despite the potential Pareto-improvement. Even for the most favorable parameter combination considered, such a reform would not find political support in the initial population. The retirees and many middle aged would lose, only younger workers would benefit.

Of course, the present framework could be extended in various other directions. In future work we plan to analyze three specific extensions. First, we will keep the current taxbenefit linkage but reduce the level of the unfunded pension system. Since our model abstracts from annuity markets, the public pension system acts as a substitute for an annuity insurance. Reducing the level of the pay-as-you-go system might therefore reduce efficiency. Second, we plan to look closer at the interaction between the tax and the public pension system. More specifically, we would like to know how the optimal progressivity of the pension system changes, when we alter the progressivity of the income tax. Finally, we plan to introduce the social assistance system in Germany. The latter will probably reduce the efficiency gains from the improved intragenerational risk sharing in the present model. However, a means-tested basic income guarantee could not act as a substitute for a progressive pension system, since the insurance effect of the former only applies to a small group of agents.

\section{References}

Auerbach, A.J. and L.J. Kotlikoff (1987): Dynamic fiscal policy, Cambridge University Press, Cambridge.

Barski, R., T. Juster, M. Kimball and M. Shapiro (1997): Preference parameters and behavioral heterogeneity: an experimental approach in the health and retirement survey, Quarterly Journal of Economics 12, 537-580.

Bomsdorf, E. (2003): Sterbewahrscheinlichkeiten der Periodensterbetafeln für die Jahre 2000 bis 2100, Eul Verlag, Köln. 
Boskin, M., L.J. Kotlikoff, D. Puffert and J. Shoven (1987): Social security: A financial appraisal across and within generations, National Tax Journal 40, 19-34.

Casamatta, G., H. Cremer and P. Pestieau (2000): The political economy of social security, Scandinavian Journal of Economics 102, 503-522.

Cecchetti, S.G., P.S. Lam and N.C. Mark (2000): Asset pricing with distorted beliefs: Are equity returns too good to be true? American Economic Review 90, 787-805.

Conde-Ruiz, J.I. and V. Galasso (2005): Positive arithmetic of the welfare state, Journal of Public Economics 89, 933-955.

Conesa, J.C. and D. Krueger (1999): Social security reform with heterogeneous agents, Review of Economic Dynamics 2, 757-795.

Conesa, J. C. and D. Krueger (2005): On the optimal progressivity of the income tax code, forthcoming in: Journal of Monetary Economics.

De Nardi, M. S. İmrohoroğlu and T. J. Sargent (1999): Projected U.S. demographics and social security, Review of Economic Dynamics 2, 575-615.

Deutsches Institut für Wirtschaftsforschung (DIW) (2005): Verteilung von Vermögen und Einkommen in Deutschland, Wochenbericht des DIW Berlin Nr. 11, 199-207.

Dohmen, T., A. Falk, D. Huffman, U. Sunde, J. Schupp and G.G. Wagner (2005): Individual risk attitudes: New evidence from a large, representative experimentallyvalidated survey, DIW Discussion Papers 511, Berlin.

Epstein, L.G. and S.E. Zin (1991): Substitution, risk aversion, and the temporal behavior of consumption and asset returns: An empirical analysis, Journal of Political Economy 99, 263-286.

Fehr, H. (1999): Welfare effects of dynamic tax reforms, Mohr Siebeck, Tuebingen.

Fehr, H. (2000): Pension Reform during the demographic transition, Scandinavian Journal of Economics 102, 419-443.

Fenge, R. (1995): Pareto-efficiency of the pay-as-you-go pension system with intragenerational fairness, Finanzarchiv 52, 357-363.

Flood, L., J. Hansen and R. Wahlberg (2003): Household labor supply and welfare participation in Sweden, IZA Discussion Paper No. 769. 
Heer, B. and M. Trede (2003): Efficiency and distribution effects of a revenue-neutral income tax reform, Journal of Macroeconomics 25, 87-107.

Huang, H., S. İmrohoroğlu and T. J. Sargent (1997): Two computations to fund social security, Macroeconomic Dynamics 1, 7-44.

Huggett, M. and G. Ventura (1999): On the distributional effects of social security reform, Review of Economic Dynamics 2, 498-531.

Institut der Deutschen Wirtschaft (2004): Deutschland in Zahlen, Köln.

Krüger, D. and F. Kubler (2005): Pareto improving social security reform when financial markets are incomplete? mimeo, University of Frankfurt.

Meister, W. and W. Ochel (2005): Sozialabgabenfreibetrag und Beschäftigung, ifo Schnelldienst 58, H. 7, 16-20.

Matsen, E. and Ø. Thøgersen (2004): Designing social security - A portfolio choice approach, European Economic Review 48, 883-904.

Nishiyama, S. and K. Smetters (2003): Consumption taxes and economic efficiency in a stochastic OLG economy, forthcoming in: Journal of Political Economy.

OECD (2005): Pensions at a glance: Public policies across OECD countries, Paris.

Schneider, H. and H. Bonin (2005): Wohlfahrts- und Verteilungseffekte eines allgemeinen Freibetrags bei den Sozialabgaben, IZA Discussion Paper No. 1490, Bonn.

Sinn, H.-W. (2000): Why a funded pension is useful and why it is not useful, International Tax and Public Finance 7, 389-410.

Storesletten, K., C.I. Telmer and A. Yaron (1999): The risk-sharing implications of alternative social security arrangements, Carnegie-Rochester Conference Series on Public Policy 50, 213-259.

Thøgersen, Ø. (1998): A note on intergerational risk sharing and the design of pay-asyou-go pension programs, Journal of Population Economics 11, 373-378.

Wagener, A. (2003): Pensions as a portfolio problem: fixed contribution rates vs. fixed replacement rates reconsidered, Journal of Population Economics 16, 111-134.

Wagener, A. (2004): On intergenerational risk sharing within social security schemes, European Journal of Political Economy 20, 181-206. 


\section{CESifo Working Paper Series}

(for full list see www.cesifo-group.de)

1505 Peter A. Zadrozny, Necessary and Sufficient Restrictions for Existence of a Unique Fourth Moment of a Univariate GARCH(p,q) Process, July 2005

1506 Rainer Niemann and Corinna Treisch, Group Taxation, Asymmetric Taxation and Cross-Border Investment Incentives in Austria, July 2005

1507 Thomas Christiaans, Thomas Eichner and Ruediger Pethig, Optimal Pest Control in Agriculture, July 2005

1508 Biswa N. Bhattacharyay and Prabir De, Promotion of Trade and Investments between China and India: The Case of Southwest China and East and Northeast India, July 2005

1509 Jean Hindriks and Ben Lockwood, Decentralization and Electoral Accountability: Incentives, Separation, and Voter Welfare, July 2005

1510 Michelle R. Garfinkel, Stergios Skaperdas and Constantinos Syropoulos, Globalization and Domestic Conflict, July 2005

1511 Jesús Crespo-Cuaresma, Balázs Égert and Ronald MacDonald, Non-Linear Exchange Rate Dynamics in Target Zones: A Bumpy Road towards a Honeymoon - Some Evidence from the ERM, ERM2 and Selected New EU Member States, July 2005

1512 David S. Evans and Michael Salinger, Curing Sinus Headaches and Tying Law: An Empirical Analysis of Bundling Decongestants and Pain Relievers, August 2005

1513 Christian Keuschnigg and Martin D. Dietz, A Growth Oriented Dual Income Tax, July 2005

1514 Fahad Khalil, David Martimort and Bruno Parigi, Monitoring a Common Agent: Implications for Financial Contracting, August 2005

1515 Volker Grossmann and Panu Poutvaara, Pareto-Improving Bequest Taxation, August 2005

1516 Lars P. Feld and Emmanuelle Reulier, Strategic Tax Competition in Switzerland: Evidence from a Panel of the Swiss Cantons, August 2005

1517 Kira Boerner and Silke Uebelmesser, Migration and the Welfare State: The Economic Power of the Non-Voter?, August 2005

1518 Gabriela Schütz, Heinrich W. Ursprung and Ludger Wößmann, Education Policy and Equality of Opportunity, August 2005

1519 David S. Evans and Michael A. Salinger, Curing Sinus Headaches and Tying Law: An Empirical Analysis of Bundling Decongestants and Pain Relievers, August 2005 
1520 Michel Beine, Paul De Grauwe and Marianna Grimaldi, The Impact of FX Central Bank Intervention in a Noise Trading Framework, August 2005

1521 Volker Meier and Matthias Wrede, Pension, Fertility, and Education, August 2005

1522 Saku Aura and Thomas Davidoff, Optimal Commodity Taxation when Land and Structures must be Taxed at the Same Rate, August 2005

1523 Andreas Haufler and Søren Bo Nielsen, Merger Policy to Promote 'Global Players'? A Simple Model, August 2005

1524 Frederick van der Ploeg, The Making of Cultural Policy: A European Perspective, August 2005

1525 Alexander Kemnitz, Can Immigrant Employment Alleviate the Demographic Burden? The Role of Union Centralization, August 2005

1526 Baoline Chen and Peter A. Zadrozny, Estimated U.S. Manufacturing Production Capital and Technology Based on an Estimated Dynamic Economic Model, August 2005

1527 Marcel Gérard, Multijurisdictional Firms and Governments' Strategies under Alternative Tax Designs, August 2005

1528 Joerg Breitscheidel and Hans Gersbach, Self-Financing Environmental Mechanisms, August 2005

1529 Giorgio Fazio, Ronald MacDonald and Jacques Mélitz, Trade Costs, Trade Balances and Current Accounts: An Application of Gravity to Multilateral Trade, August 2005

1530 Thomas Christiaans, Thomas Eichner and Ruediger Pethig, A Micro-Level 'Consumer Approach’ to Species Population Dynamics, August 2005

1531 Samuel Hanson, M. Hashem Pesaran and Til Schuermann, Firm Heterogeneity and Credit Risk Diversification, August 2005

1532 Mark Mink and Jakob de Haan, Has the Stability and Growth Pact Impeded Political Budget Cycles in the European Union?, September 2005

1533 Roberta Colavecchio, Declan Curran and Michael Funke, Drifting Together or Falling Apart? The Empirics of Regional Economic Growth in Post-Unification Germany, September 2005

1534 Kai A. Konrad and Stergios Skaperdas, Succession Rules and Leadership Rents, September 2005

1535 Robert Dur and Amihai Glazer, The Desire for Impact, September 2005

1536 Wolfgang Buchholz and Wolfgang Peters, Justifying the Lindahl Solution as an Outcome of Fair Cooperation, September 2005 
1537 Pieter A. Gautier, Coen N. Teulings and Aico van Vuuren, On-the-Job Search and Sorting, September 2005

1538 Leif Danziger, Output Effects of Inflation with Fixed Price- and Quantity-Adjustment Costs, September 2005

1539 Gerhard Glomm, Juergen Jung, Changmin Lee and Chung Tran, Public Pensions and Capital Accumulation: The Case of Brazil, September 2005

1540 Yvonne Adema, Lex Meijdam and Harrie A. A. Verbon, The International Spillover Effects of Pension Reform, September 2005

1541 Richard Disney, Household Saving Rates and the Design of Social Security Programmes: Evidence from a Country Panel, September 2005

1542 David Dorn and Alfonso Sousa-Poza, Early Retirement: Free Choice or Forced Decision?, September 2005

1543 Clara Graziano and Annalisa Luporini, Ownership Concentration, Monitoring and Optimal Board Structure, September 2005

1544 Panu Poutvaara, Social Security Incentives, Human Capital Investment and Mobility of Labor, September 2005

1545 Kjell Erik Lommerud, Frode Meland and Odd Rune Straume, Can Deunionization Lead to International Outsourcing?, September 2005

1546 Robert Inklaar, Richard Jong-A-Pin and Jakob de Haan, Trade and Business Cycle Synchronization in OECD Countries: A Re-examination, September 2005

1547 Randall K. Filer and Marjorie Honig, Endogenous Pensions and Retirement Behavior, September 2005

1548 M. Hashem Pesaran, Til Schuermann and Bjoern-Jakob Treutler, Global Business Cycles and Credit Risk, September 2005

1549 Ruediger Pethig, Nonlinear Production, Abatement, Pollution and Materials Balance Reconsidered, September 2005

1550 Antonis Adam and Thomas Moutos, Turkish Delight for Some, Cold Turkey for Others?: The Effects of the EU-Turkey Customs Union, September 2005

1551 Peter Birch Sørensen, Dual Income Taxation: Why and how?, September 2005

1552 Kurt R. Brekke, Robert Nuscheler and Odd Rune Straume, Gatekeeping in Health Care, September 2005

1553 Maarten Bosker, Steven Brakman, Harry Garretsen and Marc Schramm, Looking for Multiple Equilibria when Geography Matters: German City Growth and the WWII Shock, September 2005 
1554 Paul W. J. de Bijl, Structural Separation and Access in Telecommunications Markets, September 2005

1555 Ueli Grob and Stefan C. Wolter, Demographic Change and Public Education Spending: A Conflict between Young and Old?, October 2005

1556 Alberto Alesina and Guido Tabellini, Why is Fiscal Policy often Procyclical?, October 2005

1557 Piotr Wdowinski, Financial Markets and Economic Growth in Poland: Simulations with an Econometric Model, October 2005

1558 Peter Egger, Mario Larch, Michael Pfaffermayr and Janette Walde, Small Sample Properties of Maximum Likelihood Versus Generalized Method of Moments Based Tests for Spatially Autocorrelated Errors, October 2005

1559 Marie-Laure Breuillé and Robert J. Gary-Bobo, Sharing Budgetary Austerity under Free Mobility and Asymmetric Information: An Optimal Regulation Approach to Fiscal Federalism, October 2005

1560 Robert Dur and Amihai Glazer, Subsidizing Enjoyable Education, October 2005

1561 Carlo Altavilla and Paul De Grauwe, Non-Linearities in the Relation between the Exchange Rate and its Fundamentals, October 2005

1562 Josef Falkinger and Volker Grossmann, Distribution of Natural Resources, Entrepreneurship, and Economic Development: Growth Dynamics with Two Elites, October 2005

$1563 \mathrm{Yu}-\mathrm{Fu}$ Chen and Michael Funke, Product Market Competition, Investment and Employment-Abundant versus Job-Poor Growth: A Real Options Perspective, October 2005

1564 Kai A. Konrad and Dan Kovenock, Equilibrium and Efficiency in the Tug-of-War, October 2005

1565 Joerg Breitung and M. Hashem Pesaran, Unit Roots and Cointegration in Panels, October 2005

1566 Steven Brakman, Harry Garretsen and Marc Schramm, Putting New Economic Geography to the Test: Free-ness of Trade and Agglomeration in the EU Regions, October 2005

1567 Robert Haveman, Karen Holden, Barbara Wolfe and Andrei Romanov, Assessing the Maintenance of Savings Sufficiency Over the First Decade of Retirement, October 2005

1568 Hans Fehr and Christian Habermann, Risk Sharing and Efficiency Implications of Progressive Pension Arrangements, October 2005 